\title{
Economic Feasibility Evaluation of Building Passive
}

\section{Houses}

\author{
Ievgenii Iurchenko ${ }^{1}$, Olena Koval ${ }^{1}$, Mykola Savytskyi ${ }^{1}$ and Karim Limam ${ }^{2}$ \\ 1. Department of Reinforce-Concrete and Stoune Constructions, State Higher Education Establishment "Pridneprovsk State \\ Academy of Civil Engineering and Architecture”, Dnipropetrovsk 49600, Ukraine \\ 2. LaSIE (Laboratory of Engineering Sciences for Environment), University of La Rochelle 17042, France
}

Received: January 24, 2014 / Accepted: February 27, 2014 / Published: June 30, 2014.

\begin{abstract}
The research presents an improved method of rational design of energy-efficient low-rise residential buildings according to their life cycle. The mathematical model for finding the optimal version of draft power-efficient residential building has been developed. For conditions of Ukraine the optimization problem has been set and solved (finding the optimal version of the draft energy-efficient buildings). The calculations prove the fact that the construction of passive houses in Ukraine today is economically feasible. Scientific and practical regulations, outlined in the research, can be used by all participants of the investment programs, and energy-efficiency projects, renovation projects and developing normative-technical documents.
\end{abstract}

Key words: Energy efficiency, low-rise residential buildings, architectural and structural systems, specific heat consumption, rational design, life cycle of buildings.

\section{Introduction}

When lists weights related to energy costs for a given housing (construction, use, total), GWP100 [1], the construction phase is quite low, even negligible compared to the phase use of conventional buildings. Several Swedish studies [2, 3] show that indeed, but when we look at buildings with very low energy consumption, we begin to see a balance between energy required to build and energy used during its use [4]. Now looking distribution of energy consumption during the lifetime of a building, Adalberth [2] shows that in conventional constructions, a large part of the energy used during the life cycle of the building due to the consumption of heating and ventilation. It shows in a more recent study [5] and in the low energy consumption buildings, the proportion of the consumption of heating and ventilation of the same

Corresponding author: Karim Limam, associate professor, research fields: building and environment. E-mail: klimam01@univ-lr.fr. order of magnitude as the proportion of hot water for consumption and can be lower than the share specific electricity and lighting.

The studies conducted by the consulting firm EURIMA (Ecofys on the Order of Manufacturers Isolation Materials Association), showed that the potential energy savings consumed by the buildings in the world is $50 \%$. This means that with the help of an effective strategy for improving buildings, energy efficiency can reduce total energy consumption by almost $17 \%$ [2].

In European countries, energy efficiency increase of buildings has been one of the main development directions in the construction industry during the last decade. This direction is urgent in the Ukraine as well, for example, in the Dnipropetrovsk region, a number of projects to increase energy efficiency in existing buildings has been developed on the basis of SHEE "Prydniprovsk State Academy of Civil Engineering and Architecture" [6-8, 14-16]. 
The new version of the European Union Directive on the energy efficiency of houses [9] requires bringing construction standards and requirements of the European countries for the house construction with minimal energy consumption, namely houses with a high level of energy efficiency. Considering the difficult economic situation in Ukraine, there is the economic component of energy efficiency, based on an economic assessment of the design solutions feasibility to housing [10-12]. On that basis, the urgent problem in low-rise housing construction of Ukraine is improving scientific statements of the energy-efficient building design based on life cycle.

The main objective is to present the theoretical principles of rational design methods of energy-efficient low-rise residential buildings to meet their life cycle, as well as coverage obtained with the developed technique results.

\section{The Mathematical Model}

On the basis of Higher Education Establishment "PSACEA", a rational design method of energy-efficient low-rise residential buildings has been developed including their life cycle [6, 7]. In general, the rational design of residential buildings is to develop a project for a given optimality criterion that would satisfy all the applicable building standards for the given constraints. To compare alternative versions of energy-efficient residential buildings, it is proposed to use the method of calculating the total (discounted) value, which is to convert all the construction and operation costs of a residential building for the entire expected life cycle in the estimated amount in the year of the expected building demolition.

On the assumption that the capital cost of one-time construction and dismantling, and annual operating costs for the entire life cycle are constant, a mathematical model has been developed to find the optimal variant of a residential building energy efficiency [6, 7]. The proposed mathematical model is formulated in the form of a nonlinear programming task: to minimize the total cost of the building construction, operation and dismantling under certain restrictions. In general, the mathematical model is formulated by the Eq. (1):

$$
3_{i, t}=\mathrm{K}_{i} g^{t}+E_{i} \frac{g^{t}-1}{g-1}+D_{\mathrm{i}}
$$

where, $3_{i, t}$-total (discounted) costs of building;

$K_{i}$-capital investments for the building construction in accordance with $i$-variant;

$E_{i}$-operating costs of building maintenance according to $i$ - variant;

$D_{i}$-costs associated with the removal of building project (disposing its building materials);

$t$-life cycle (service life) (year);

$g$-build-up factor: $g=1+p$;

$p$-discount rate that equals the investor's acceptable profit rate divided by capital;

$g^{t}$-discount factor (present value factor) at the end of the billing period: $g^{t}=(1+p)^{t}$;

$\left(g^{t}-1\right) /(g-1)$ - growth factor of current payments, equated to the future point in time for a number of homogeneous periods of payments.

Mathematical task model of finding an optimal energy-efficient building is formulated in the form of a nonlinear programming task: to minimize the total costs of the building construction, operation and dismantling Eq. (1) under certain restrictions. Taking into account the cost components, mathematical model is:

$$
\begin{aligned}
& 3_{i, t}=\left(\Pi 3+H P+C \Pi+I C+\Pi_{p} 3\right)_{i} g^{t}+ \\
& +\left[\begin{array}{l}
\mathrm{C}_{h \text { eat }} \times Q^{\text {heat }}+C_{e l} \times Q^{e l}+C_{v} \times \mathrm{V}^{v}+C_{g a s} \times \mathrm{V}^{\text {gas }}+ \\
+0.0245\left(\Pi 3+H P+C \Pi+I C+\Pi_{p} 3\right)
\end{array}\right]_{i}^{\frac{g^{t}-1}{g-1}+D_{\mathrm{i}} \rightarrow \mathrm{min}}
\end{aligned}
$$

ПЗ—-direct expenses;

$H P$-overhead;
CП—estimated profit (planned savings).

$I C$ - the purchase and installation cost of process 
equipment and engineering systems;

$\Pi_{\mathrm{p}} 3$ - other costs associated with additional costs for construction and installation and commissioning in the winter time, the costs for construction of temporary buildings and structures, etc..

$C_{\text {heat }}$ - thermal energy cost (UAH/Gcal);

$C_{e l}$-electricity cost (UAH/kW per year);

$C_{v}$-water supply cost $\left(\mathrm{UAH} / \mathrm{m}^{3}\right)$;

$C_{\text {gas }}$ - gas cost $\left(\mathrm{UAH} / \mathrm{m}^{3}\right)$;

$Q^{\text {heat }}$-annual heat consumption of the building during the heating period (Gcal);

$Q^{e l}$ - annual electricity consumption of the building (kW per year);

$V^{\nu}$-annual water consumption of the building $\left(\mathrm{m}^{3}\right)$; $V^{g a s}$ - annual gas consumption of the building $\left(\mathrm{m}^{3}\right)$.

Limitations of the optimization task are:

- the duration of the heating period $(G D)$;

- the cost of heat, electricity, gas and water;

- the building service life $t$ (years);

- the rate of investment capital $p-0 \ldots 20 \%$;

- tpecific fuel consumption $q \quad(\mathrm{~kW}$ per year $/\left(\mathrm{m}^{2} \cdot\right.$ year $\left.)\right)$.

The Eq. (2) allows to determine the economic feasibility of energy efficiency houses, and also to assess the investment attractiveness of the various innovative energy-saving technologies in Ukraine. So it is necessary to compare housing projects versions, using, as a constraint optimization tasks, specific heat consumption $q\left(\mathrm{~kW} \cdot\right.$ year $/\left(\mathrm{m}^{2} \cdot\right.$ year $\left.)\right)$, which should be compared with control flow coefficients of heat energy:

- according to current standards $q \leq \mathrm{E} \max$ $\left(\mathrm{kW} \cdot\right.$ year $/\left(\mathrm{m}^{2} \cdot\right.$ year $\left.)\right)$;

- with the standards of a low-energy house $q \leq 70$ $\mathrm{kW}$ per year $/\left(\mathrm{m}^{2} \cdot\right.$ year $)$;

- with the standards of a passive house $q \leq 15 \mathrm{~kW}$ per year $/\left(\mathrm{m}^{2} \cdot\right.$ year $)$.

\section{Methodology and Results}

Eq. (2) presents the opportunity to determine the economic feasibility of energy-efficient and passive houses. Building the best option is the rational combination of design, engineering and technological components of the building's energy efficiency, which will provide the minimum total cost of the construction, operation and dismantling. For formulating and solving the problem of choosing the optimal design of energy-efficient low-rise residential building, a basic version two-story apartment building has been developed, designed in accordance with the requirements of Ukrainian national construction regulation B.2.2-15-2005 "Residential buildings Basics". Based on the architectural and planning decisions of the basic version, and based on the principles of passive house construction, passive house version has been design. The main technical and economic indicators of the versions under consideration are summarized in Table 1. Based on the basic, version seventeen versions of the building project have been designed and analyzed, which are different construction capital costs and thermal energy consumption in the facility operation (Table 2 ).

The data presented in Tables 1 and 2 indicate that value appreciation of a passive house compared to the basic variant is $25.7 \%$.

The task solution, namely the choice of two proposed versions of optimal residential building design, will provide an opportunity to answer the question: What standards of housing (active or "passive housing") are economically justified today. The versions at issue differ in the level of thermal protection envelope and using a variety of energy-saving technologies. Both options meet the requirements of the applicable building standards (energy-efficient classes-A and B).

In the analysis, the tasks of rational design (search for the optimal variant) with the following restrictions have been set and solved:

- the lifecycle of the building 50 years at the current cost of energy (Fig. 1a);

- the lifecycle of the building 50 years at the projected cost of energy (Figs. 1b-1d). 
Table 1 Version indicators of the residential building project.

\begin{tabular}{|c|c|c|}
\hline Indicator & Basic version & Passive house \\
\hline Project description & $\begin{array}{l}\text { Frame-panel construction } \\
\text { scheme, no basement. } \\
\text { wall insulation-100 mm; } \\
\text { attic floor insulation-200 mm; } \\
\text { ground floor insulation- } 50 \mathrm{~mm} \text {; } \\
\text { windows-single glazing }\end{array}$ & $\begin{array}{l}\text { Frame-panel construction scheme, no basement; } \\
\text { sealed envelope enclosing: wall insulation-250 mm; } \\
\text { attic floor insulation- } 400 \mathrm{~mm} \text {; } \\
\text { attic floor insulation-250 mm; } \\
\text { windows-energy-efficient triple-glazing } R=1.4 \\
\mathrm{~m}^{2} \cdot \mathrm{kW} \text {; } \\
\text { ventilated air recuperation; } \\
\text { passive use of solar energy. }\end{array}$ \\
\hline Total area $\left(\mathrm{m}^{2}\right)$ & 127.3 & \\
\hline Heated room area $\left(\mathrm{m}^{2}\right)$ & 124.45 & \\
\hline Heated volume $\left(\mathrm{m}^{3}\right)$ & 349 & \\
\hline Capital costs for building* $\left(€ / \mathrm{m}^{2}\right)$ & 252.0 & 316.4 \\
\hline Specific annual heat consumption $\left(\mathrm{kWh} / \mathrm{m}^{2}\right)$ & 96.1 & 14.8 \\
\hline $\begin{array}{l}\text { Annual operating costs }(€) \\
\text { at a cost Gcal }=25.1 €\end{array}$ & 260.0 & 40.0 \\
\hline $\begin{array}{l}\text { Annual operating costs }(€) \\
\text { at the projected cost } \mathrm{Gcal}=37.4 €\end{array}$ & 386.3 & 59.3 \\
\hline $\begin{array}{l}\text { Annual operating costs }(€) \\
\text { at the projected cost } \mathrm{Gcal}=75 €\end{array}$ & 773.0 & 119.0 \\
\hline
\end{tabular}

*-capital costs value for the construction of houses (including VAT (value-added tax)) with no cost of engineering equipment and communications, excluding overhead and deductions, and net profit.

Table 2 Energy-efficient house varieties.

\begin{tabular}{|c|c|c|c|c|c|}
\hline $\begin{array}{l}\text { Varieties } \\
\text { No. }\end{array}$ & Project description & $\begin{array}{l}\text { Capital } \\
\text { construction } \\
\text { Investments } \\
\text { UAH. } *(€)^{*}\end{array}$ & $\begin{array}{l}\text { Specific heat } \\
\text { consumption, } \\
q_{\text {бyd, }}(\mathrm{kW} \text { per } \\
\left.\text { year } / \mathrm{m}^{2}\right)\end{array}$ & $\begin{array}{l}\text { Energy effic } \\
\text { According } \\
\text { to state } \\
\text { building } \\
\text { standards }\end{array}$ & $\begin{array}{l}\text { European } \\
\text { classification }\end{array}$ \\
\hline 1. & $\begin{array}{l}\text { Basic version (insulation walls thickness-100 mm; attic } \\
\text { floor-200 mm; ground floor-50 mm; windows- } \\
\text { single-glass unit) }\end{array}$ & $\begin{array}{l}342,978.0 \\
(€ 32,054)\end{array}$ & 96.1 & B & $\begin{array}{l}\text { "New house"to } 150 \\
\mathrm{~kW} \text { per year } / \mathrm{m}^{2}\end{array}$ \\
\hline 2. & Additional wall insulation by $50 \mathrm{~mm}$ & $\begin{array}{l}352,804.8 \\
(€ 32,972)\end{array}$ & 87.5 & B & $\begin{array}{l}\text { "New house" to } 150 \\
\mathrm{~kW} \text { per year } / \mathrm{m}^{2}\end{array}$ \\
\hline 3. & Additional wall insulation by $100 \mathrm{~mm}$ & $\begin{array}{l}362,624.4 \\
(€ 33,890)\end{array}$ & 82.3 & B & $\begin{array}{l}\text { "New house" to } 150 \\
\mathrm{~kW} \text { per year } / \mathrm{m}^{2}\end{array}$ \\
\hline 4. & Additional insulation in the attic floor by $50 \mathrm{~mm}$ & $\begin{array}{l}346,324.8 \\
(€ 32,367)\end{array}$ & 94.2 & B & $\begin{array}{l}\text { "New house" to } 150 \\
\mathrm{~kW} \text { per year } / \mathrm{m}^{2}\end{array}$ \\
\hline 5. & Additional insulation in the attic floor $100 \mathrm{~mm}$ & $\begin{array}{l}349,664.4 \\
(€ 32,679)\end{array}$ & 92.9 & B & $\begin{array}{l}\text { "New house" to } 150 \\
\mathrm{~kW} \text { per year/m }\end{array}$ \\
\hline 6. & Additional floor insulation on the ground by $50 \mathrm{~mm}$ & $\begin{array}{l}344,473.2 \\
(€ 32,194)\end{array}$ & 92.8 & B & $\begin{array}{l}\text { "New house" to } 150 \\
\mathrm{~kW} \text { per year } / \mathrm{m}^{2}\end{array}$ \\
\hline 7. & Additional floor insulation on the ground by $100 \mathrm{~mm}$ & $\begin{array}{l}345,960.0 \\
(€ 32,332)\end{array}$ & 90.9 & B & $\begin{array}{l}\text { "New house" to } 150 \\
\mathrm{~kW} \text { per year/m }\end{array}$ \\
\hline 8. & $\begin{array}{l}\text { Additional wall insulation by } 50 \mathrm{~mm} \text {; attic floor by } 50 \\
\mathrm{~mm} \text {; ground floor by } 50 \mathrm{~mm}\end{array}$ & $\begin{array}{l}357,632.4 \\
(€ 33,424)\end{array}$ & 82.3 & B & $\begin{array}{l}\text { "New house" to } 150 \\
\mathrm{~kW} \text { per year } / \mathrm{m}^{2}\end{array}$ \\
\hline 9. & $\begin{array}{l}\text { Additional wall insulation by } 100 \mathrm{~mm} \text {; attic floor by } \\
100 \mathrm{~mm} \text {; ground floor by } 100 \mathrm{~mm}\end{array}$ & $\begin{array}{l}372,278.4 \\
(€ 34,792)\end{array}$ & 73.8 & B & $\begin{array}{l}\text { "New house" to } 150 \\
\mathrm{~kW} \text { per year } / \mathrm{m}^{2}\end{array}$ \\
\hline 10. & $\begin{array}{l}\text { Double-glass unit installation } \\
\mathrm{R}=0.8 \mathrm{~m}^{2} \cdot \mathrm{K} / \mathrm{W}\end{array}$ & $\begin{array}{l}347,817.6 \\
(€ 32,506)\end{array}$ & 87.3 & B & $\begin{array}{l}\text { "New house" to } 150 \\
\mathrm{~kW} \text { per year } / \mathrm{m}^{2}\end{array}$ \\
\hline 11. & Double- glass unit installation $\mathrm{R}=1.14 \mathrm{~m}^{2} * \mathrm{~K} / \mathrm{W}$ & $\begin{array}{l}354,987.6 \\
(€ 33,176)\end{array}$ & 81.4 & B & $\begin{array}{l}\text { "New house" to } 150 \\
\mathrm{~kW} \text { per year/m } / \mathrm{m}^{2}\end{array}$ \\
\hline 12. & $\begin{array}{l}\text { Additional wall insulation by } 50 \mathrm{~mm} \text {; attic floor by } 50 \\
\mathrm{~mm} \text {; ground floor by } 50 \mathrm{~mm} \\
\text { Double-glass unit installation } \mathrm{R}=0.8 \mathrm{~m}^{2} \cdot \mathrm{K} / \mathrm{W}\end{array}$ & $\begin{array}{l}362,472.0 \\
(€ 33,876)\end{array}$ & 73.4 & B & $\begin{array}{l}\text { "New house" to } 150 \\
\mathrm{~kW} \text { per year } / \mathrm{m}^{2}\end{array}$ \\
\hline 13. & $\begin{array}{l}\text { Additional wall insulation by } 100 \mathrm{~mm} \text {; attic floor by } 100 \\
\mathrm{~mm} \text {; ground floor by } 100 \mathrm{~mm} \\
\text { Double-glass unit installation } \mathrm{R}=1.14 \mathrm{~m}^{2} \cdot \mathrm{K} / \mathrm{W}\end{array}$ & $\begin{array}{l}384,288.0 \\
(€ 35,915)\end{array}$ & 58.9 & A & $\begin{array}{l}\text { "Low power } \\
\text { consumption house" } \\
\text { to } 70 \mathrm{~kW} \text { per year } / \mathrm{m}^{2}\end{array}$ \\
\hline
\end{tabular}


Table 2 continued

\begin{tabular}{|c|c|c|c|c|c|}
\hline $\begin{array}{l}\text { Varieties } \\
\text { No. }\end{array}$ & Project description & $\begin{array}{l}\text { Capital } \\
\text { construction } \\
\text { Investments } \\
\text { UAH. } *(€)^{*}\end{array}$ & $\begin{array}{l}\text { Specific heat } \\
\text { consumption, } \\
q_{\text {буд, }}(\mathrm{kW} \text { per } \\
\left.\text { year } / \mathrm{m}^{2}\right)\end{array}$ & $\begin{array}{l}\text { Energy effi } \\
\text { According } \\
\text { to state } \\
\text { building } \\
\text { standards }\end{array}$ & $\begin{array}{l}\text { European } \\
\text { classification }\end{array}$ \\
\hline 14. & Installation of waste heat exchangers (recuperator) & $\begin{array}{l}372,034.8 \\
(€ 34,770)\end{array}$ & 65.9 & B & $\begin{array}{l}\text { "Low power } \\
\text { consumption house" } \\
\text { to } 70 \mathrm{~kW} \text { per year } / \mathrm{m}^{2}\end{array}$ \\
\hline 15. & $\begin{array}{l}\text { Additional wall insulation by } 50 \mathrm{~mm} \text {; attic floor by } 50 \\
\mathrm{~mm} \text {; ground floor by } 50 \mathrm{~mm} \\
\text { Double--glass unit installation } \mathrm{R}=0.8 \mathrm{~m}^{2} \cdot \mathrm{K} / \mathrm{W} \\
\text { Installation of waste heat exchangers (recuperator) }\end{array}$ & $\begin{array}{l}391,528.8 \\
(€ 36,592)\end{array}$ & 43.3 & A & $\begin{array}{l}\text { "Low power } \\
\text { consumption house" } \\
\text { to } 70 \mathrm{~kW} \text { per year } / \mathrm{m}^{2}\end{array}$ \\
\hline 16. & $\begin{array}{l}\text { Additional wall insulation by } 100 \mathrm{~mm} \text {; attic floor by } 100 \\
\text { mm; ground floor by } 100 \mathrm{~mm} \\
\text { Multiple-glass unit installation } \mathrm{R}=1.14 \mathrm{~m}^{2} \cdot \mathrm{K} / \mathrm{W} \\
\text { Installation of waste heat exchangers (recuperator) }\end{array}$ & $\begin{array}{l}413,344.8 \\
(€ 38,630)\end{array}$ & 28.7 & A & $\begin{array}{l}\text { "Low power } \\
\text { consumption house", } \\
\text { to } 70 \mathrm{~kW} \text { per year } / \mathrm{m}^{2}\end{array}$ \\
\hline 17. & Passive house & $\begin{array}{l}431,016.0 \\
(€ 40,282)\end{array}$ & 14.8 & A & $\begin{array}{l}\text { "Passive house" } \\
\text { to } 15 \mathrm{~kW} \text { per year } / \mathrm{m}^{2}\end{array}$ \\
\hline
\end{tabular}

* - capital costs value for the construction of houses (including VAT) with no cost of engineering equipment and communications, excluding overhead and deductions, and net profit.

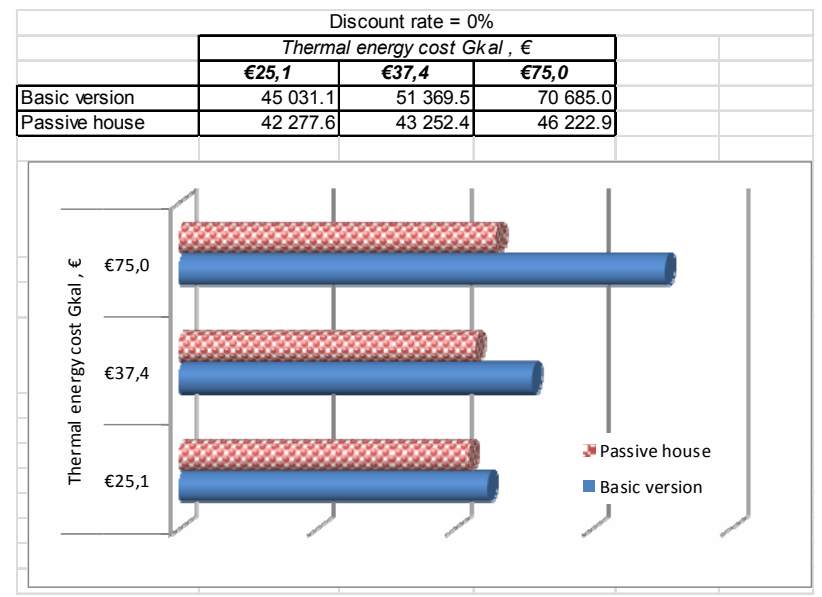

(a)

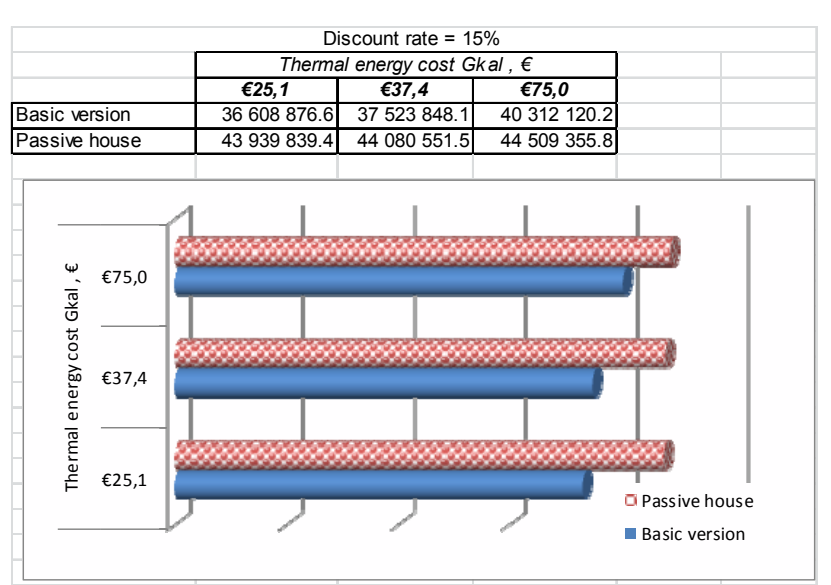

(c)

\begin{tabular}{|l|c|c|c|}
\hline \multicolumn{1}{|c|}{ Discount rate $=10 \%$} \\
\cline { 2 - 4 } & \multicolumn{3}{|c|}{ Thermal energy cost Gkal, $\boldsymbol{\epsilon}$} \\
\cline { 2 - 4 } & $\boldsymbol{\epsilon} \mathbf{2 5 , 1}$ & $\boldsymbol{\epsilon 3 7 , 4}$ & $\boldsymbol{\mathbf { 7 7 5 } , \mathbf { 0 }}$ \\
\hline Basic version & 4064931.8 & 42124777.5 & 4662106.4 \\
\hline Passive house & 4775179.9 & 4797870.7 & 4867018.5 \\
\hline
\end{tabular}

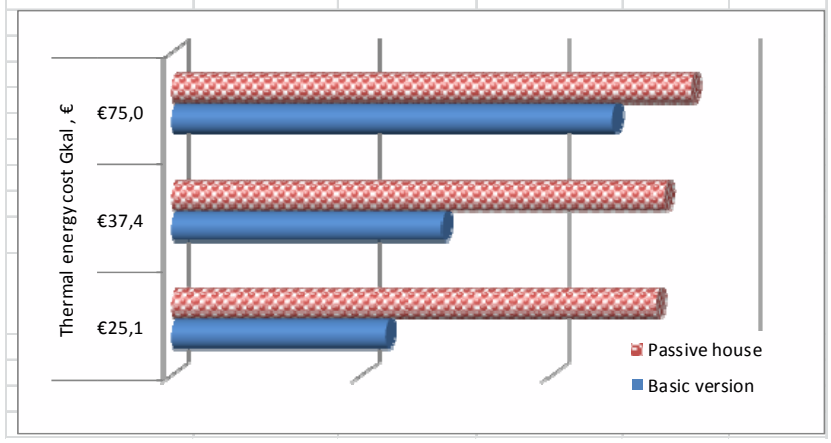

(b)
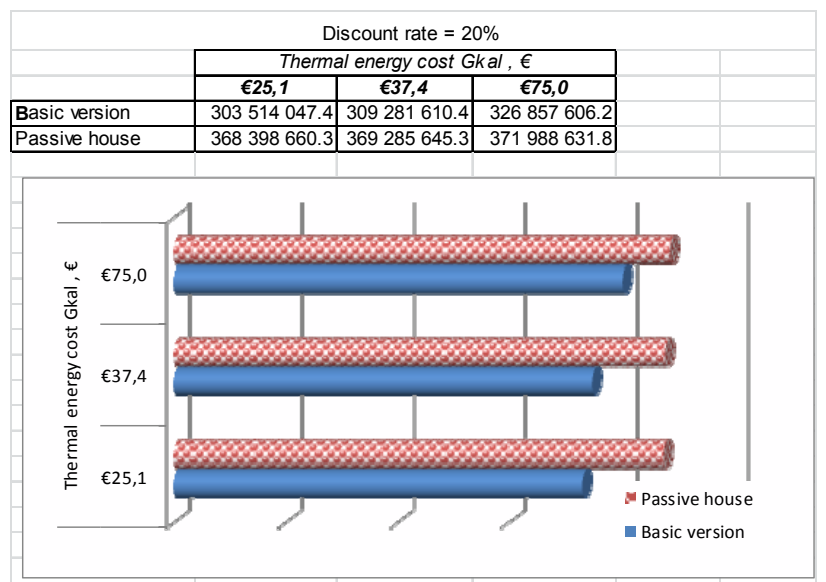

(d)

Fig. 1 Housing projects total cost of low-rise residential apartment building by the passive house version and basic version, $€$ : at discount rates-(a) 0 ; (b) $10 \%$; (c) $15 \%$; and (d) $20 \%$. 
(1) At a discount rate of 0 (Fig. 1a), the total construction costs of the building construction, operation and dismantling by the passive house version are lower than the basic one. Taking into account changes in the money value at time (a discount rate of $10 \%, 15 \%$, and $20 \%$ ), the optimal version is the basic one. The calculations prove the fact that the construction of passive houses in Ukraine today is economically feasible only in interest-free loans.

(2) At projected higher energy costs (Figs. 1b-1d), the implementation of energy-efficient measures makes economic sense.

The following scientific and practical results are given in the research on the basis of the numerical experiment:

- ranking of low-rise buildings by all energy efficiency classes for all temperature zones of Ukraine has been made for the first time;

- specific heat consumption data of low-rise residential buildings with different architectural and structural systems have been calculated and classified;

- energy efficiency change regularities of one-, two-, three-, and four-storey buildings from their architectural and structural systems for all temperature zones of Ukraine have been determined [15, 16];

- the system of specific heat consumption indicators, which are consistent with the applicable element wise requirements to heat transfer resistance of the houses walling, has been suggested for all the temperature zones of Ukraine.

\section{Conclusions}

To give some answers as to the feasibility of undertaking the construction of passive houses in Ukraine, and watch the gain in global terms (construction, operation, demolition) benefit of a project like this, we compared alternative variants of residential buildings energy efficient using a method of calculating the total cost (actual or estimated according to the evolution of the market), which is to convert all construction costs and operating costs of residential buildings throughout scheduled service (up to year estimated for the planned demolition of the building). The findings are clear, in light of soaring energy prices, the $\mathrm{BBC}$ or passive design is considered a fast and presents an alternative sustainable economic future for Ukrainian.

\section{References}

[1] B. Peuportier, Life cycle assessment applied to the comparative evaluation of single family houses in the French context, Energy and Buildings [Online], 33 (5) (2001)

443-450, http://www.sciencedirect.com/science/article/B6V2V.

[2] K. Adalberth, Energy use during the life cycle of single unit dwellings: Examples, Building and Environment [Online], $32 \quad$ (4) (1997) 321-329, http://www.sciencedirect.com/science/article/B6V23-3 SMT80B.

[3] B.N. Winther, A.G. Hestnes, Solar versus green: The analysis of a norwegian row house, Solar Energy 66 (6) (1999) 387-393.

[4] A. Joelsson, L. Gustavsson, A life cycle energy perspective on the passive house concept, in: The First International Conference on Building Energy and Environment, Dalian, China, 2008.

[5] K. Adalberth, Energy use in four multi-family houses during their life cycle, International Journal of Low Energy and Sustainable Buildings 1 (1999) 1-22.

[6] I.L. Iurchenko, Development of the energy saving projects in the buildings of budget organizations on the basis of reinvestment, Manuscript, 2004.

[7] O.O. Koval, Energy efficiency of low-rise residential buildings of architectural constructive systems, Manuscript, 2012.

[8] I.L. Iurchenko, Improved methods of rational design of low-rise residential buildings based on life cycle, Theoretical foundations of civil engineering, Warsaw University, Warsaw, 2011.

[9] Directive 2010/31/EU of the European parliament and of the council of 19 May 2010 on the energy performance of buildings, Official Journal of the European Union, EU, 2010.

[10] S.M. Nitenko, The Law of Ukraine about Energy Efficiency, Verkhovna Rada of Ukraine, 1994, p. 14.

[11] Construction of Buildings and Structures, Ministry of Construction of Ukraine, 2006.

[12] Design, Guidelines for the Development and Drafting of the Energy Passport Buildings for New Construction and Remodeling, Ministry of Regional Development 
Construction of Ukraine, 2008.

[13] Energy performance of buildings - Calculation of energy use for space heating and cooling, European Committee for Standardization, 2008.

[14] M.V. Savytskyi, T.Y. Shevchenko, I.L. Iurchenko, O.O. Koval, Improving energy efficiency of residential buildings of the old building, Building, Materials Sciences, Mechanic Engineering: Collection of Scientific Papers Issue 50 (2009) 489-495.
[15] I.L. Iurchenko, Projects to improve energy efficiency of existing residential buildings in Ukraine, Building, Materials Sciences, Mechanic Engineering: Collection of Scientific Papers Issue 65 (2012) 677-683.

[16] I.L. Iurchenko, economic feasibility of energy-efficient and passive house construction in Ukraine, Building, Materials Sciences, Mechanic Engineering: Collection of Scientific Papers Issue 68 (2013) 462-468. 